\title{
Erratum: Clinical use of Dieletrophoresis separation for live Adipose derived stem cells
}

\author{
Francesco M Marincola
}

\begin{abstract}
After publication of this article [1] it was brought to the journal's attention that David Morrow was unaware of the submission of this article in his name and did not consent to become an author. He points out that he was not involved in the creation of the article. Readers are also alerted that in the absence of any evidence from an institutional investigation to confirm or refute the reliability of the data, there are ongoing concerns and this article's findings should be interpreted with caution. Appropriate editorial action will be taken if further information becomes available.
\end{abstract}

Received: 11 September 2014 Accepted: 11 September 2014

Published online: 30 September 2014

\section{Reference}

1. Wu AY, Morrow DM: Clinical use of Dieletrophoresis separation for live Adipose derived stem cells. J Trans/ Med 2012, 10:99.

\section{Submit your next manuscript to BioMed Central and take full advantage of:}

- Convenient online submission

- Thorough peer review

- No space constraints or color figure charges

- Immediate publication on acceptance

- Inclusion in PubMed, CAS, Scopus and Google Scholar

- Research which is freely available for redistribution

Submit your manuscript at www.biomedcentral.com/submit

( ) Biomed Central 